\title{
The Information Content of Earnings on Stock Prices: The Kuwait Stock Exchange
}

\author{
Rashid Al-Qenae \\ University of Kuwait, Kuwait \\ Carmen Li \\ University of Essex, UK \\ Bob Wearing \\ University of Essex, UK
}

This paper investigates the incremental information content of earnings and other macroeconomic variables for share prices within the prices leading earnings' framework. We find evidence supporting the phenomenon of 'prices leading earnings' for the Kuwait Stock Exchange (KSE) after controlling for basic macroeconomic indicators. That is, the estimated earnings response coefficient is found to be sensitive (and significant) to the leading periods and it increased when more leading periods were included. The results suggest that prices anticipate earnings and hence provide useful information to KSE investors (JEL G140, G150, O160).

Keywords: earnings response coefficients, Kuwait Stock Exchange, priceleading earnings.

\section{Introduction}

The role of accounting earnings on equity valuations has been a topic of considerable research since the 1960s. Research in this area is based

${ }^{*}$ We would like to thank participants, in particular Ivan Brick, of the $7^{\text {th }}$ Annual Conference of the Multinational Finance Society, Philadelphia, USA, for constructive suggestions. We are also grateful for the helpful comments of three anonymous referees. The usual disclaimer applies.

(Multinational Finance Journal, 2002, vol. 6, no. 3\&4, pp. 197-221)

(C)Multinational Finance Society, a nonprofit corporation. All rights reserved.

DOI: $10.17578 / 6-3 / 4-3$ 
on the notion that "If accounting earnings are related to stock prices, the EMH [efficient market hypothesis] suggests that earnings can be useful measures or indices of value contrary to the 1960s argument that earnings numbers are useless because they are not measured using a single concept of income." (Watts and Zimmerman, [1986, p.37]).

Ball and Brown (1968), in their seminal work, analyzed the priceearnings relation over a one-year return period. The one-year return period corresponds with the period covered in annual reports. In their study they observed that, to a large extent, the market anticipates the information content of an annual report prior to the date of its release. Much of the data contained in the annual report is made available on a timelier basis by many existing interim sources of information so earnings may be reflected in the security's price before they have been announced (Grant, 1980; Bublitz, Frecka and Mckeown, 1985). This is the basic idea underlying the theory of prices leading earnings. Indeed, Kothari (1992) and Kothari and Sloan (1992) argued that stock prices contain information about future earnings because market expectations are based on a richer information set than the one embedded in contemporaneous earnings. They showed that the estimation of the price earnings relation improved by exploiting the information contained in leading period returns.

The basic price-earnings relationship has been tested for different markets and modified to examine the informational content of other accounting numbers (e.g. cash flows) and macro-micro variables (e.g. national income, size of firms, etc.) beyond earnings itself. Among others, Beaver, Lambert and Ryan (1987) have tested it for US companies; Donnelly and Walker (1995) study the share price anticipation of earnings of UK companies and showed that the estimation of the price-earnings relation improves when firms with transient earning are excluded from the sample; and $\mathrm{Li}$ and Wearing (2000) investigate the prices leading earnings and explore the information content of cash flows for the Australian Stock Market.

In the last decade, equity flows to developing countries have increased substantially and therefore stock markets in these countries have received increasing attention from policy makers and researchers. Efforts to improve the functioning of financial markets in developing countries have often focused on financial liberalisation policies and a smaller role for the state in credit allocation, improving the role of banks 
as financial intermediaries, and financial governance. However, most of the existing research on the information content of earnings relates to that of developed financial markets and relatively little research have been undertaken in developing markets mainly because of the relatively small volume of trade and the lack of readily available and consistent data.

Our motivation is to make a contribution to the field by investigating the sensitivity of earnings response coefficients to leading period returns in an emerging market. To do this, we mainly follow the methodology suggested by Kothari and Sloan (1992). The choice of the Kuwait Stock Exchange over the period 1981 to 1997 was dictated by both its rapid growth over a relatively short period and the possibility of direct data collection. We do not pretend to generalize our findings to all emerging markets but, rather, we see our paper as a starting point for future studies and debate.

The next section provides a brief literature survey and a description of the Kuwaiti Stock Exchange. Section III explains the data used in this study and specifies the model to be tested. Section IV discusses the empirical results. Finally, we end with conclusions and lines for further research.

\section{Brief Literature Survey and Evolution of the Kuwaiti Stock Exchange}

As stated earlier, one of the most active research areas is the role of earnings information on equity valuation. In particular, how does the market react when earnings figures are released? How are the stock prices of firms affected and how much of the earnings announcements explain abnormal security returns? Empirical tests of the price-earnings relation are plentiful for developed economies but not so for developing countries.

According to the definition of the World Bank (1995) any stock market located in a developing country is considered as an 'emerging market' irrespective of how well developed the stock market itself might be. This definition links stock market development potential with the economy's overall development potential. Stock markets play an important role in encouraging savings and investment and hence, 
economic development. In particular, as argued by Claessens (1995) and Harvey (1995), stock markets in developing countries can have beneficial effects in that they act as vehicles for raising capital, at the same time enabling investors to diversify wealth and risk. Stock markets can also provide a screening and monitoring function and therefore assist in indicating profitable investment opportunities because stock prices quickly reflect changes concerning firms and the economy.

Harvey (1993) and Buckberg (1993) pointed out that many emerging markets offer yields in excess of developed market returns suggesting that there might be unexploited profit opportunities to be made by investing in these markets. However, emerging markets exhibit high volatile stock prices arising from the fact that they are small markets with insufficient integration into the global economy and informational imperfections. They typically tend to be 'noisier' with fewer trades taking place, have limited reporting requirements and less information updates than in developed markets. Expected returns are not only affected by the uncertain economic and financial conditions of the firms but also by the political and economic environment of the country, which is generally less stable than in developed countries. In this context, understanding the relationship between stock prices (in advance of earnings announcements) and the published earnings figures is very important to investors, financial intermediaries and regulators. If the information contribution of earnings to investors is useful, then earnings should exhibit considerable explanatory power with respect to price revisions both cross-sectional and over time (Lev 1989).

\section{A. Review of the Basic Price Earnings Relation}

The price-earnings regression commonly tested is (e.g. Beaver et al. 1980, Kothari and Sloan, 1992, Brown et al. 1987)

$$
R_{i, t}=\beta_{0, i}+\beta_{1, i} U E_{i, t}+\varepsilon_{i, t},
$$

where $R_{i, t}$ is excess return over expected return for firm $i$ measured over the fiscal quarter or year $t ; U E_{i t}$ is reported earnings minus the market expectation of earnings, scaled by the price of the security at the beginning of period $t ; \beta_{0, i}$ is the constant term and $\varepsilon_{i, t}$ is a white noise disturbance term. The estimated coefficient $\beta_{1, i}$ is the well-known 
earnings response coefficient (ERC), that is, the increment to the stock price of firm $i$ caused by a unit increase in its earnings. The constant term is assumed to be stationary over time. The strength of the priceearnings relation (or the usefulness of earnings information to investors) is measured in terms of the magnitude of the estimated ERC and the correlation between returns and earnings $\left(R^{2}\right)$.

Although there is evidence that prices react to earnings, empirical research seems not to describe adequately the effects of the release of earnings on contemporaneous market prices. The estimated effect of earnings on prices is found to be small and there is a low correlation between returns and earnings changes. Nonetheless, if the unexpected earnings proxy measures the market's assessment with error, the results may lead to incorrect inferences. Therefore, one way of improving the understanding and estimation of the price-earnings relation is by exploring alternative ways of measuring earnings that are unexpected by the market.

Beaver, Lambert and Morse (1980) made an important contribution re-interpreting the price-earnings relation. They derived a relationship between changes in share prices and changes in earnings by expanding the information upon which earnings are conditioned to include variables other than the prior earnings history. They recognized that, "in general, the assessed distribution of future earnings conditional upon past earnings will differ from the assessed distribution of future earnings conditional upon past earnings and past prices. This will occur if prices convey information about future earnings that is not conveyed by the past earnings." (p.4). They characterize earnings as a mixture of two processes: one which includes the impact of earnings on events that also affect prices; whereas, the other (called 'garbling') considers the impact of earnings on events with no effect on security prices. In this way, changes in prices depend on changes in expectations concerning future earning and therefore, share prices may include information about future earnings not reflected in contemporaneous earnings.

Researchers have also recognized that the relation between returns and stock prices varies across firms and over time. For instance, Brown et al. (1987) showed that unexpected earnings that are based on financial analysts' earnings forecasts provide a better explanation for 'abnormal' returns than other proxies. They argued that the measurement error in unexpected earnings might change on the basis of 
the firm's peculiarities and that in general, information and earnings figures of large companies tend to be released to the market earlier and on a more frequent basis than that of small companies. Furthermore, Kormendi and Lipe (1987) explained why a similar increase in 'unexpected' or 'surprise' announcement of accounting earnings in two firms might result in different stock price reactions. They showed that the impact of a current earnings surprise on stock prices depended on how much this surprise is expected to persist in the future.

Ou and Penman (1989) claimed that 'incomplete earnings' happens because contemporaneous earnings do not fully reflect value-relevant events. On the one hand, earnings may reflect events that have already been observed by the market prior to the contemporaneous returns period. On the other hand, earnings might include expenditures incurred during the same returns period but the market recognized their benefits only in later periods. They investigated the relevance of financial statements in forecasting future earnings, explaining contemporaneous stock price movements and predicting future price movements. They have reopened the debate about exploring if other accounting data can be used to explain 'abnormal' returns (e.g. Easton, Harris and Ohlson [1992]; Ali and Pope [1995]; Cheng, Liu and Schaefer, [1997]).

From a different perspective, Easton and Harris (1991) considered the strength of the price-earnings relation. They criticize the use of change of earnings as a measure of unexpected earnings and discuss the relevance of the level of earnings for the evaluation of the earnings prices relationship. They argue that the " $[\mathrm{m}]$ ost value-relevant events occurring during a specific time interval should be part of the concurrent earnings, provided that the interval is sufficiently long" (p.121). Measurement errors arise from a) value-relevant events occurring during the return interval but recognized in earnings in the future and $b$ ) value-relevant events happening before the return interval but recognised in earnings during the interval. For long intervals, these errors are relatively small compared to the value-relevant events recognised in earnings during the interval.

Kothari (1992) and Kothari and Sloan (1992) also explored the strength of the price-earnings association. In contrast to previous studies where the price-earnings regression in 'levels' includes prices and earnings, both deflated by the beginning-of-the year share price; they examined the price-earnings regressions when "prices lead 
earnings' i.e. prices contain information about future earnings that is not reflected in the past time-series of earnings. ${ }^{1}$ They found that by exploiting the earnings forecasts embedded in the security prices, they were able to reduce the measurement error bias caused by a noisy proxy for the market expectation of future earnings and also obtain a better fit of the price-earnings regression.

\section{B. The Kuwaiti Stock Exchange}

The stock market in the 1950s was considered to be in a 'transition' period because the government faced the difficult task of planning and organizing a growing economy with many social and political changes. ${ }^{2}$ It was only a decade later that the Kuwaiti government started planning the foundation of the stock exchange. The first commercial company act regulated the creation of shareholding companies, joint ventures, partnerships and public companies as well as the administration and liquidation of existing companies. Nonetheless, the trading of securities was still kept unregulated. ${ }^{3}$

The Kuwait Stock Exchange (KSE) was officially formed in March 1983. ${ }^{4}$ Further discussions took place to help identify the role of the KSE, its administration and budget, the listing and acceptance of securities, arbitration, the conduct of brokerage firms and trading disputes. The KSE opened for trading in a new permanent building in September 1984.

After 1985, several important rules were enacted. The introduction of a price unit system helped protect the market from sharp price

1. A typical price-earnings regression in 'levels' is a regression of annual return on the contemporaneous year's earnings deflated by the beginning of the year price. Kothari (1992) argues that the term 'level' is not accurate because earnings deflated by price is effectively the accounting rate of return on the market value of equity, hence it can be considered a change variable. The "changes" specification uses the annual earnings change (deflated by the beginning of the year price) as the independent variable.

2. More details in Al-Menthree (1987) and Sarkoh (1993).

3. See "Amiri Decrees and Laws Organizing the Stock Exchange", Pamphlet of the KSE, Legislation and Advice Authority (1996).

4. Data on the KSE started to be recorded in 1981 when it was active but not officially formed. 
movements. Indeed, the new system allowed share prices to move five units only during a trading session. In 1986, a ministerial resolution authorised forward trading in the KSE and a Market Committee (MC) was appointed to set up the rules and regulations to control forward dealings. Another ministerial resolution was passed in the same year to introduce market makers to the market. The markets maker's role was to stabilize the market and act as a cushion for any abnormality that might occur. The Market Committee established the clearing chamber in 1987. The main responsibility of the Kuwaiti Clearing Company (KCC) was to settle obligations and rights arising form market transactions and to notify listed companies of ownership changes. All investors and traders had to have an account with the $\mathrm{KCC}$ in order to trade in the KSE. ${ }^{5}$

In 1987, the government allowed all listed companies to buy back $10 \%$ of their shares as treasury stock and encourage companies to act as market makers for their own shares. There were only eleven brokerage firms and the MC stressed that the market needed to increase the number of firms. Note that the role of brokers in the market was restricted to the execution of trading deals only. In fact, the MC started the trading process in the new market by having written bids on the boards in a restricted hall for brokers only. In addition, the MC introduced the Kuwaiti Dinar bond market to the KSE. The bond market was not as popular as the stock market but gave additional options to both investors and companies. Finally, the MC created an unofficial parallel market for trading in Gulf company shares that did not meet the requirements of the official market. The total number of Gulf companies in the parallel market reached thirteen and they had different trading areas and also different trading hours from that of the official stock market.

In May 1990, a Ministerial Act was passed to organize the creation and trading in closed-end investment portfolios. It gave companies the right to establish a portfolio fund if investing on behalf of others. Furthermore, to attract more investment to the market, it allowed all residents (not only citizens) to invest in these funds.

After the Kuwait-Iraq war, the government passed more laws and

5. See Annual Economic Report, KSE (1987). 
resolutions to facilitate trading in the market. In 1993, citizens from neighbouring Gulf countries were allowed to own shares in shareholding companies and to trade in the KSE. The MC also passed a law regarding changes to listing requirements for shareholding companies. This new law combined the unofficial parallel market with the official market and decreased the minimum capital required for companies to be listed from five to one million Kuwaiti Dinars. Finally, the MC approved the new regulation of forward dealings in shares of listed companies in 1996. Although forward dealings were allowed only through companies authorized by the KSE, the financial community welcomed it because it added a new financial instrument to the market. The positive effect of the various regulatory measures following the Kuwait-Iraq war can be seen from the appendix that shows the increase in market capitalization over the period 1994 to 1997 . The overall market capitalization increased by $177 \%$ and the strongest growth took place in the banking, real estate and non-Kuwaiti sectors.

\section{Hypothesis, Model Specification and Data Collection}

\section{A. Hypothesis and Model Specification}

We mainly follow the methodology proposed by Kothari and Sloan (1992) to test the hypothesis of prices leading earnings in the KSE. Given the panel nature of our sample, the prices leading earnings are tested for fixed effects and random effects. The fixed effect model (FEM) assumes that differences across firms can be captured by differences in the constant term $\left(\alpha_{i}\right)$

$$
\begin{gathered}
R_{i, t}=\beta_{0}+\alpha_{i}+\beta_{1} U E_{i, t}+\varepsilon_{i, t}, \\
E\left[\varepsilon_{i, t}\right]=0, E\left[\varepsilon_{i, t}^{2}\right]=\sigma_{e}^{2} .
\end{gathered}
$$

In contrast, the random effect model (REM) assumes that the firm specific effects are randomly distributed across cross sectional units, so the above equation is reformulated as 


$$
\begin{gathered}
R_{i, t}=\beta_{0}+\beta_{1} U E_{i, t}+v_{i}+\varepsilon_{i, t}, \\
E\left[\varepsilon_{i, t}\right]=E\left[v_{i}\right] 0, E\left[\varepsilon_{i, t}^{2}\right]=\sigma_{e}^{2}, E\left[v_{i, t}^{2}\right]=\sigma_{v}^{2}, E\left[\varepsilon_{i, t} v_{i, t}\right]=0,
\end{gathered}
$$

where $v_{i}$ is the random disturbance characterising the $i^{\text {th }}$ firm and it is assumed constant through time.

A 'large' value of the Breusch-Pagan Lagrange multiplier test rejects the null hypothesis that $E\left[v_{i}\right]=0$ and favours the REM over FEM. However, the REM assumes that $E\left[v_{i} x_{i, t}\right]=0$ and the Hausman statistic tests for the validity of this assumption. If the Hausman test is rejected (i.e. $v_{i}$ and $x_{i, t}$ are correlated), then we use the "semi-robust" estimates of variance from the population-averaged model using GEE (generalised equation estimation) that only requires that the model correctly specify the mean. $\mathrm{R}^{2}$ across FEM and REM are not strictly comparable and unfortunately goodness of fit methodology for GEE is still in the research phase. ${ }^{6}$

Note that the fixed effect estimator amounts to using OLS to estimate:

$$
\begin{gathered}
R_{i, t}-\bar{R}_{i}=\beta_{1}\left(U E_{i, t}-\overline{U E}_{i}\right)+\left(\varepsilon_{i, t}-\bar{\varepsilon}_{i}\right), \\
\bar{R}_{i}=\Sigma_{t} R_{i, t} / T_{i}, \overline{U E}_{i}=\Sigma_{t} U E_{i, t} / T_{i}, \bar{\varepsilon}_{i}=\Sigma_{t} \varepsilon_{i, t} / T_{i},
\end{gathered}
$$

and therefore, it does not provide an estimate for the time-invariant variables (e.g. industry type), but it provides estimates of the timevariant indicators (e.g. real gross national product).

The dependent variable $R_{i, t}$ is defined as $P_{i, t} / P_{i, t-\tau^{*}}$ That is, one plus the buy-and-hold return including the current year dividends but excluding the prior year dividends, over the period $t-\tau$ to $t$ and $t \geq 1$. Note that when $\tau>1, P_{i, t} / P_{i, t-\tau}$ encapsulates the leading-period returns à la Kothari and Sloan (1992). Our proxy of unexpected earnings is $X_{i, t} / P_{i, t-\tau}$ where $X_{i, t}$ is the level of contemporaneous year's earnings per

6. See Stata Reference Manual, Release 7.0 for more details. 
share which is deflated by the beginning of the year price. ${ }^{7}$ The estimated coefficient on earnings is the firm i's earning response coefficient (ERC). When $\tau=1$, a 'benchmark' case, the regression considers contemporaneous changes on earnings scaled by share price at the beginning of the period. Likewise, when $\tau=2$, it considers two overlapping years' returns scaled by share price at the beginning of the period. As $\tau$ (the return measure interval) increases, more of the expectation of earnings will be impounded in the share price. As usual, $\beta_{0}$ is the constant term and $\varepsilon_{i t}$ and $v_{I}$ are the random disturbances.

We apply panel regression analysis to test the usefulness of the price-earnings relation in four different time frames. For the contemporaneous price-earnings, we measure returns over one year; for one period leading prices, returns are measured over two years; for two period leading prices, returns are measured over three years; and finally, for three period leading prices, returns are measured over four years.

Additionally, it has been argued that macroeconomic variables may have an effect on the price earnings relationship. Lev and Thiagarajan (1993) demonstrate the importance of applying a contextual capital market analysis by claiming that the empirical relationship between returns and earnings is notably improved after controlling for macroeconomic variables. Besides earnings, and similar to $\mathrm{Li}$ and Wearing (2000), we include real gross national product (realgnp), real interest rates (rmmk) and the inflation rate (inflcpi) as additional regressors but with a year lag to attenuate the problem of simultaneity. High real GNP is associated with an affluent economy and investors might therefore expect high share returns. ${ }^{8}$ High real interest rates are associated with low returns because companies are expected to face high finance costs. In general, high inflation reflects economic crisis which is expected to have adverse effects on share returns. Nevertheless, investors may associate high inflation with high share returns if they believe companies will be able to recover increased costs

7. See Easton and Harris (1991), Kothari (1992) and Kothari and Sloan (1992) for a discussion on earnings levels versus changes in earnings as alternative specifications of the price-earnings regression.

8. The Kuwait economy depends heavily on oil. Price of oil and real GNP exhibit a strong, positive and significant correlation. We prefer to quote the regression with real GNP because of its wider application. 
through increases in the selling prices of their products. We also control for industry type and included a dummy variable that identifies each firm as belonging to the banking, investment, insurance, and real estate, manufacturing, and service sectors. Lastly, we account for the Iraq invasion of Kuwait in 1990 by adding a dummy variable that takes the value of 1 in 1990 and zero otherwise.

\section{B. Sample Design and Data Collection}

Emerging markets face a major shortcoming in not having appropriate data. Databases seldom exist and if they exist, they are often incomplete or inaccurate. Computerized databases are found less frequently in developing markets. The KSE started to computerize its data in 1996. Therefore, for this study, the KSE data from 1981 through to 1997 was collected manually and then transformed into a computerized format.

The sample data of this study was restricted to companies which were listed in the KSE with available annual trading data. By the end of 1997, there were 65 listed companies across seven sectors in the KSE:

\begin{tabular}{|lrr|}
\hline \multicolumn{2}{l}{ Industry classificationNumber } & Percentage \\
\hline Banks & 8 & 12.31 \\
Investment & 15 & 23.08 \\
Insurance & 4 & 6.15 \\
Real Estate & 7 & 10.77 \\
Manufacturing & 16 & 24.62 \\
Services & 10 & 15.38 \\
Food & 5 & 7.69 \\
\hline Total & 65 & 100.00 \\
\hline
\end{tabular}

In the KSE, the end of the fiscal year is December 31, but the deadline for submitting annual reports is March 31. This difference between the end of the fiscal year and the deadline for submission might have an effect on the price-earnings relationship. Therefore, we estimate separate price-earnings regressions for the closing prices of 
shares at the end of December and at the end of March. The closing prices of the end of December will be based on the 12-month return measure over the fiscal year (Kothari and Zimmerman [1995]). The closing prices of the end of March analysis will be based on a return period extending from 9 months prior to 3 months after the fiscal yearend, corresponding approximately with the period between earnings announcements (Easton and Harris [1991]).

We made two important modifications to the stock price data series so that they could be compared across time. Firstly, we had to adjust the outstanding number of shares and modify the dividends per share accordingly. Companies often issued bonus shares as a percentage of the total outstanding number of shares, and also companies increased their capital by issuing new shares. Secondly, we made adjustments to all listed companies affected by the split order. The 1986 stock split was mandated by the KSE for all listed companies. Before the stock split order was issued, the share par value was 1 Kuwaiti Dinar (KD), yet, the market value for some companies had increased by up to twentyseven fold. ${ }^{9}$ The stock split order was to split each share into 10 shares with the par value of 100 Fils for all listed companies in the KSE. ${ }^{10}$ This order was issued in an attempt to make the prices 'affordable', to spread the shares among a wider base of investors, and to attract more traders to the KSE.

The data for gross national product (GNP), interest rate and inflation rate were collected from the International Financial Statistics Yearbook (IMF). The interest rate is the average of daily bids and offers quotations for the interbank rate on three-month $\mathrm{KD}$ deposits and the inflation rate is based on the CPI. The real GNP and the real interest rate were deflated using the CPI.

It is important to mention that the Iraqi invasion of Kuwait took place in August 1990 and had an overwhelming effect in the Kuwaiti economy. The KSE's operations were suspended from the invasion day until September 29, 1992. The Kuwait market regulators dealt with the two-year stoppage by issuing a Ministerial Order that allowed listed companies to combine their two-year operations into the reporting year of 1990. We take this into account in constructing our data set and, as stated before, we included a dummy variable to control for the KuwaitIraqi war.

9. $1 \mathrm{KD}$ equals approximately 2 Sterling Pounds (as at 1997).

10. 100 Fils is $1 / 10$ of $\mathrm{KD}$ or $\mathrm{KD}$ equals 1000 Fils. 


\section{Empirical Findings}

Tables 1 and 2 present the econometric results for contemporaneous $(\tau$ $=1)$ returns, lead $1(\tau=2)$, lead $2(\tau=3)$ and lead $3(\tau=4)$ applying the December price and March price respectively. Tables 3 and 4 include the macroeconomic variables for all time frames. ${ }^{11}$ Given that the FEM does not provide estimates of the industry sector dummies, we also present the FEM and/or GEE when appropriate. Our choice between REM, FEM and GEE is indicated in the tables.

Table 1 reports the estimated ERC of December closing prices for the KSE data. The estimated ERC shows a significant and higher sensitivity with leading period returns. The size of the estimated ERC increases from 0.23 to 4.42 when the number of leading periods increases from 0 to 3 years and in all cases, the $t$-statistics are highly significant. The $R^{2}$ (goodness of fit) increases when the periods are led forward. These results are consistent with the price-leading earnings results found for the United States, United Kingdom and Australia.

The estimated ERC for March closing prices is presented in Table 2. The estimated ERC is significant and shows a stronger association with stock returns as the leading periods increase. That is, March prices already contain information about earnings, which have just been released by companies. These results are in line with those for December closing prices and provide support for the view that prices lead earnings.

Next we examine the effects of including macroeconomic variables and other controls on share returns. Table 3 reports the estimated ERC for December closing prices after introducing real GNP, real interest rate, inflation, industrial sector dummies and the Kuwait-Iraqi war dummy variable. The magnitude of the ERC increases when more leading periods are covered in the earnings variable, i.e. the ERC increases from 0.20 to 5.39 when the number of leading periods increases from 0 to 3 . The $R^{2}$ also improves as we incorporate more leading period returns.

As for the effects of the macroeconomic variable on the share prices, real GNP has always the expected positive effect but it is only statistically significant in $\tau=4$. Both interest rate and inflation always

11. The regressions were estimated using Stata Statistical Software Release 7.0. 


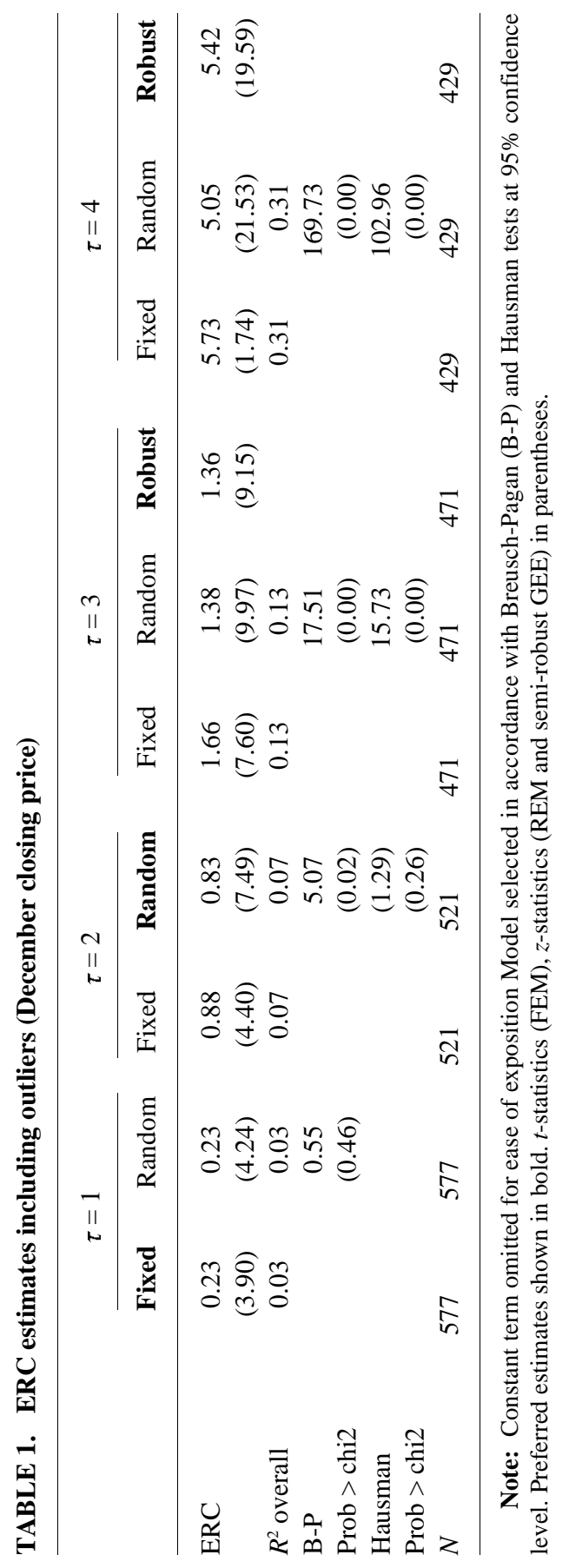




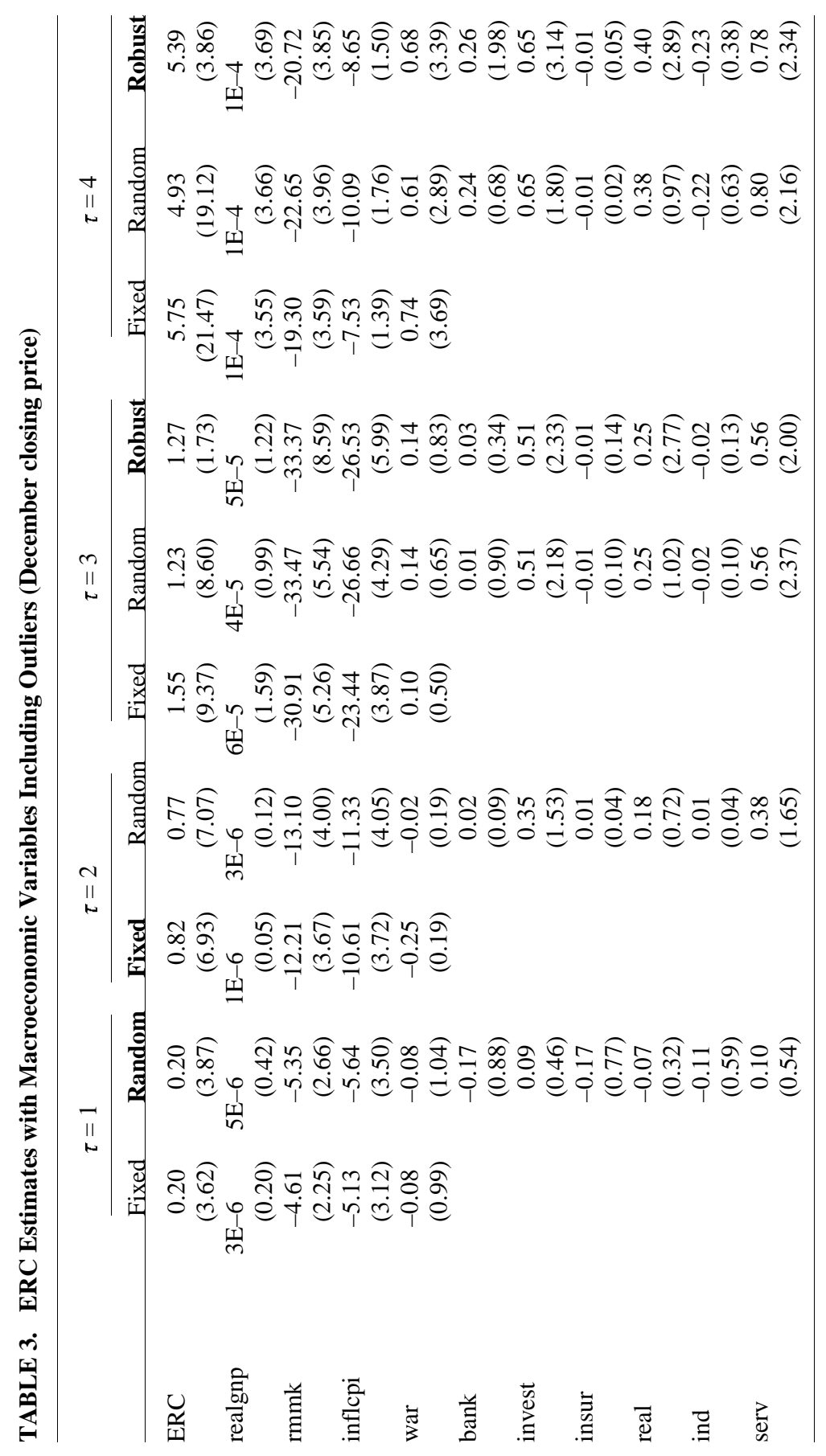




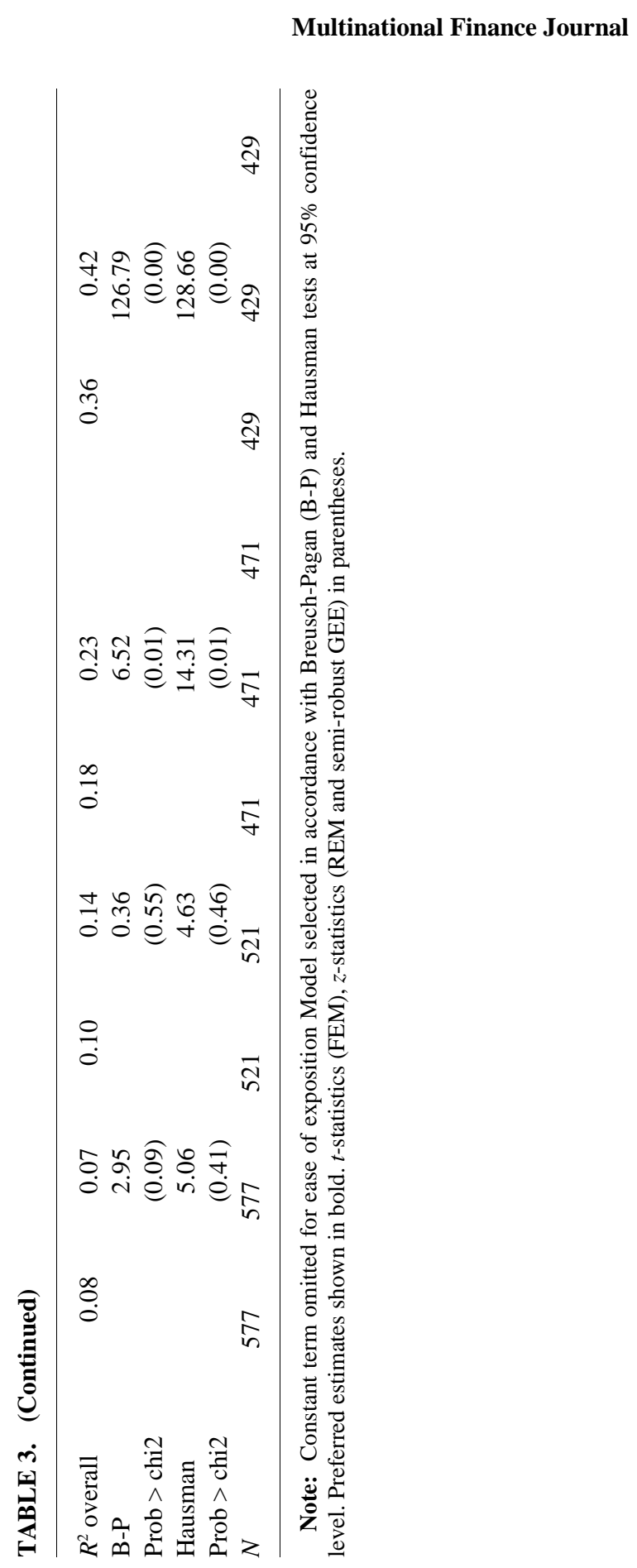


have the expected negative sign and are statistically significant in almost all cases. In other words, recessions have a detrimental effect on share returns. High real interest rates are usually associated with high financing costs faced by firms and hence, low share returns. High inflation reflects economic disequilibria and might have a negative effect on share returns. This result contrasts with the one obtained by Li and Wearing (2000) for the Australian stock market where inflation exerted a positive effect on share prices.

Recall that in 1991, a Ministerial Order was issued ordering companies to combine the results of the first half of 1990 (i.e. before the war) with the second half of 1991 . Therefore, the 1990 reported results include two events, that is the announcement of the war and the war itself. Both factors might have negative effects on share returns before and immediately after the war. As time passes, share returns may be affected positively because confidence is restored. Moreover, share prices may increase if investors believe that shares are 'undervalued'. Our results suggest that this might have been the case for the KSE. The war has a negative but insignificant effect on share returns for both the contemporaneous and one period leading return regressions; but thereafter changes to a positive sign and becomes statistically significant when share prices are led three periods.

A glance at the industry sector dummies shows that Kuwaiti firms in the investment, real estate and service sectors tend to have higher share returns after controlling for earnings and other macroeconomic variables.

It is interesting to note that the size of the ERC is only slightly smaller when we added other variables (besides earnings) than when we do not. Also, the goodness of fit improves when the macroeconomic variables are added and the periods are led forward. This suggests that focussing only on the earnings information is not likely to bias the degree to which returns anticipate earnings and that other control variables, in addition to earnings, are also helpful in explaining returns.

Table 4 reports the estimated ERC for March closing prices after controlling for macroeconomic variables, war and industry sector effects. As expected, the estimated ERC is significant and positive and increases as the leading period increases and all other variables behaved similarly to the ones presented for December.

Our results are robust to the exclusion of outliers: a) We excluded 


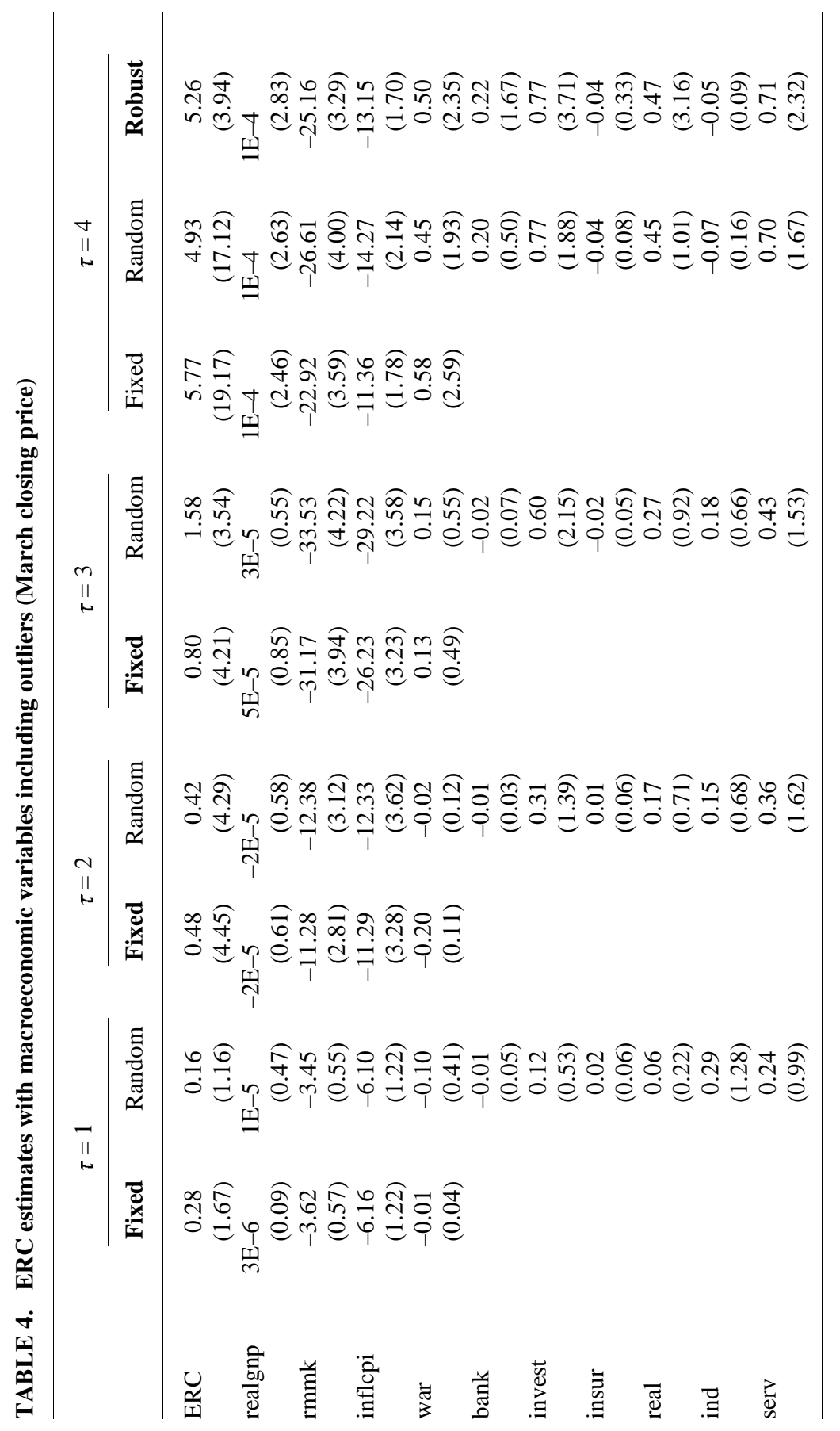




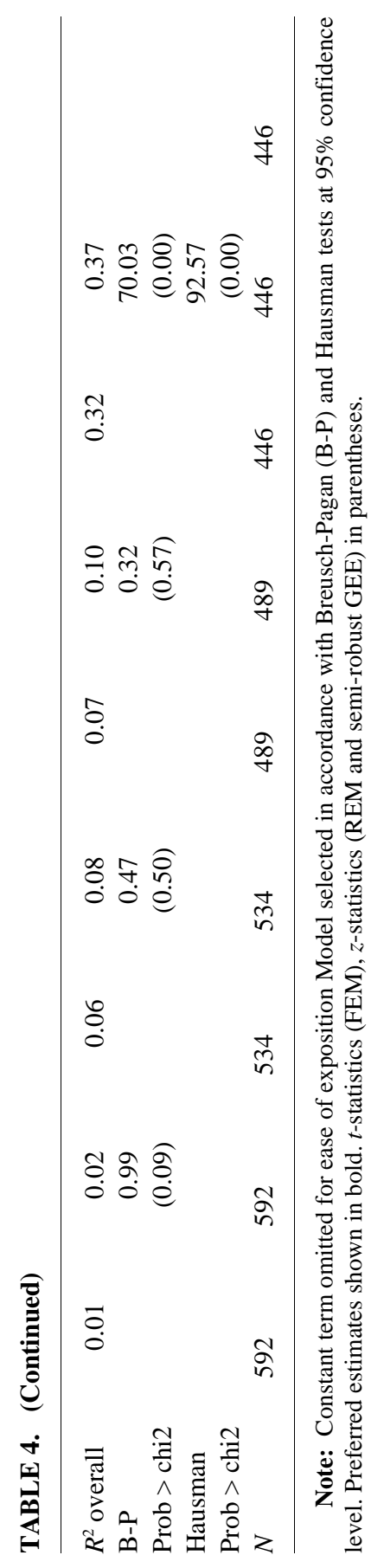


firms with more than 3 standard deviations for returns or earnings and performed the same exercise. ${ }^{12}$ b) We restricted our data set to companies listed in the KSE for the whole period of the study and with available annual trading data. This left us with a balanced panel data of 34 firms.

\section{Conclusions}

We have investigated the relationship between share returns and earnings. We have provided empirical evidence that both the ERC and the strength of the relationship between share returns and earnings improves with the inclusion of leading-period returns and other control variables i.e. macroeconomic indicators and dummy variables for industry sector and war effects. Our estimation was based on the December and March closing prices and the results were similar. In other words, the adoption of a slightly different return period did not appear to change the nature of our results. Moreover, they are robust to exclusion of outliers and changes in the sample criteria.

The KSE pattern of the returns-earnings relationship seems to follow that of the developed markets. We find results that are consistent with those of developed markets of the US (Kothari and Sloan, 1992) and the UK (Donnelly and Walker, 1995). Li and Wearing (2000), in addition to earnings, have also studied the effect of macroeconomic variables on share returns for the Australian stock market. Our findings for the KSE are generally consistent with their study except for the negative effect of inflation on share prices.

We have provided empirical support for the view that investors in the $\mathrm{KSE}$ are able to anticipate earnings in a similar manner to investors in developed markets. One might argue that information sources are adequate and regulators therefore need take no further actions with respect to improving information dissemination in the KSE. However, this would be a superficial and perhaps misleading conclusion since the way in which information is impounded into share prices is not yet well understood. Encouraging more private consulting agencies and widening

12. Not reported in this paper but available upon request. 
the brokers' role (in relation to investment advice) in the KSE may be necessary to improve the dissemination of information.

A more ambitious interpretation of our findings is that stock prices reflect investors' perception that current earnings provides them with information about future earnings and the future returns of the firm. That is, the market responds quickly to new information and anticipates earnings. Within this interpretation, our results suggest that the Kuwait stock exchange market exhibits some features of semi-strong efficiency i.e. a scenario in which stock prices incorporate all publicly available information. Note that we say 'ambitious' because we have not tested (or intended to test) the joint hypothesis of market efficiency, that is, information efficiency and a model of market equilibrium that explains the factors that affect expected returns.

One of the caveats of our study is that the results are subject to the unavoidable small nature of our sample. Another limitation was the interruption of the KSE and economic activities caused by the Iraqi invasion of Kuwait in 1990. For further research it will be interesting to follow up the future financial development of the KSE, control for persistent versus transient earnings, assess the information content of other financial statement information in addition to earnings, and to examine the 'usefulness' of earnings and other accounting information in other emerging markets.

Appendix - Kuwait Stock Market Capitalization (Million KD)

\begin{tabular}{lrrrrr}
\hline Sector & 1994 & 1995 & 1996 & 1997 & $\%$ Change \\
\hline Banks & 1,657 & 1,926 & 2,679 & 3,005 & 81 \\
Investment & 225 & 376 & 924 & 1,424 & 533 \\
Insurance & 157 & 201 & 295 & 315 & 101 \\
Real Estate & 168 & 281 & 417 & 1,012 & 502 \\
Manufacturing & 404 & 659 & 758 & 1,220 & 202 \\
Services & 344 & 496 & 658 & 945 & 175 \\
Food & 148 & 174 & 178 & 208 & 41 \\
Non-Kuwaiti & 153 & 176 & 665 & 897 & 486 \\
Total & 3,256 & 4,289 & 6,574 & 9,026 & 177 \\
\hline
\end{tabular}

Source: Kuwait Stock Market, Annual Report, various issues; Central Bank of Kuwait, Economic Report, various issues. 


\section{References}

Ali, A., and Pope, P. 1995. The incremental information content of earnings, funds flow and cash flow: The UK evidence. Journal of Business Finance and Accounting 22(1): 19-34.

Al-Menthree, S. 1987. Arabian Capital Stock Markets. Lebanon: Alrazy Publishing House.

Ball, R., and Brown, P. 1968. An empirical evaluation of accounting income numbers. Journal of Accounting Research 6(2): 159-178.

Beaver, W.H.; Lambert, R; and Morse, D. 1980. The information content of security prices. Journal of Accounting and Economics 1: 3-28.

Beaver, W.H.; Lambert, R; and Ryan, S. 1987. The information content of security prices: A second look. Journal of Accounting and Economics 9: 139-157.

Brown, L.D.; Hagerman, R.L.; Griffin, P.A.; and Zmijewski, M.K. 1987. An evaluation of alternative proxies for the market's assessments of unexpected earnings. Journal of Accounting and Economics 9: 159-193.

Bublitz, B.; Frecka, T.J.; and McKeown, J.C. 1985. Market association test and FASB statement No. 33 disclosure: A reexamination. Supplement to Journal of Accounting Research 23: 1-23.

Buckberg, E. 1993. Emerging stock markets and international asset pricing, in Claessens, S., and Gooptu, S. (eds.), Portfolio Investment in Developing Countries. Washington: The World Bank.

Cheng, C.S.A.; Liu, C.S.; and Schaefer, T.F. 1997. The value relevance of SFAS No. 95: Cash flows from operations as assessed by security market effects. Accounting Horizons September: 1-15.

Claessens, S. 1995. The emergence of equity investment in developing countries: Overview. World Bank Economic Review 9(1): 1-18.

Donnelly, R., and Walker, M. 1995. Share price anticipation of earnings and the effect of earnings persistence and firm size. Journal of Business Finance \& Accounting 22(1): 5-18.

Easton, P., and Harris, T.S. 1991. Earnings as an explanatory variable for returns. Journal of Accounting Research 29(1): 19-36.

Easton, P.; Harris, T.; and Ohlson, J. 1992. Aggregate accounting earnings can explain most of security returns. Journal of Accounting and Economics 15: 119-142.

Grant, E. 1980. Market implications of differential amounts of interim information. Journal of Accounting Research 18: 255-268.

Harvey, C. 1993. Portfolio enhancement using emerging markets and conditioning information, in Claessens, S., and Gooptu, S. (eds.), Portfolio Investment in Developing Countries. Washington: The World Bank.

Harvey, C. 1995. The risk exposure of emerging markets. World Bank Economic Review 9(1): 19-50. 
Kormendi, R.C., and Lipe, R. 1987. Earnings innovations, earnings persistence, and stock returns. Journal of Business 60(3): 323-346.

Kothari, S.P. 1992. Price-earnings regressions in the presence of prices leading earnings. Journal of Accounting and Economics 15: 173-202.

Kothari, S.P., and Sloan, R. 1992. Information in prices about future earnings. Journal of Accounting and Economics 15: 143-171.

Kothari, S., and Zimmerman, J. 1995. Price and return models. Journal of Accounting and Economics 20: 155-192.

Lev, B. 1989. On the usefulness of earnings and earnings research: Lessons and directions from two decades of empirical research. Journal of Accounting Research 27 Supplement: 153-192.

Lev, B., and Thiagarajan, R. 1993. Fundamental information analysis. Journal of Accounting Research 31(2): 190-215.

Li, C.A., and Wearing, R.T. 2000. Share prices, earnings and cash flows, in Lee, C.F. (ed.), Advances in Quantitative Analysis of Finance and Accounting. Stamford: JAI Press.

Ou, J.A., and Penman, S.H. 1989. Accounting measurement, price-earnings ratio, and the information content of security prices Journal of Accounting Research Supplement 27: 111-144.

Sarkoh, Y.Y. 1993. Shares and Trading in Shareholding Companies in Kuwait Second Edition. Kuwait: Dar Alketub.

Stata 2001. Stata Reference Manual Release 7. Texas: Stata Press.

Watts, R., and Zimmerman, J. 1986. Positive Accounting Theory, London: Prentice-Hall International

World Bank 1995. The International Finance Corporation Indexes, Washington: World Bank. 